\title{
Prevalence of consumption of psychoactive substances amongst dockers
}

\author{
Omar Laraqui ${ }^{1}$, Nadia Manar ${ }^{2,3}$, Salwa Laraqui ${ }^{3}$, Tarik Ghailan ${ }^{2,4}$, Souad Charioui ${ }^{2}$, \\ Frédéric Deschamps ${ }^{1}$, Chakib El Houssine Laraqui ${ }^{2,3}$ \\ ${ }^{1}$ Department of Occupational Health Medicine Faculty, Reims, France \\ ${ }^{2}$ Moroccan Society of Occupational Health Research, Casablanca, Morocco \\ ${ }^{3}$ Graduate School of Health Engineering, Casablanca, Morocco \\ ${ }^{4}$ Moroccan Society of Maritime Health, Tangier, Morocco
}

\begin{abstract}
Background: Dockers in the port facilities are exposed to significant psychosocial risks (stress, suffering at work, etc.) related to heavy organisational, environmental, physical, chemical constraints, etc. These workers are particularly affected by the consumption of psychoactive substances because of the dangerousness and complexity of their work. To what extent can these numerous occupational risks be at the origin of behaviour favouring the consumption of psychoactive substances? However, in our country no study has investigated toxic habits in this population. The aim of this study was to determine the prevalence of the use and misuse of psychoactive substances amongst dockers, and to appreciate the poly-consumption according to socio-demographic and occupational characteristics.

Materials and methods: This cross-sectional study was conducted amongst 665 dockers. The interview took place at the occupational health service and lasted between 15 and 20 minutes for each person respecting the confidentiality. The questionnaire covered socio-demographic characteristics, socio-professional characteristics, and toxic habits (tobacco, alcohol, cannabis and others psychotropic substances). The misuse was assessed by specific tests: Fagerström test for tobacco smoking, Cannabis Abuse Screening Test (CAST) and Alcohol Use Disorders Identification Test (AUDIT).

Results: The prevalence of use was 30.5\% for tobacco smoking, 9.1\% for cannabis smoking, and 16.5\% for alcohol consumption. The prevalence of toxic habits was significantly higher in handlers than in machinery operators: tobacco smoking ( $39.7 \%$ vs. $27 \% ; p=0.002)$, snuff tobacco $(12.5 \%$ vs. $4.6 \% ; p=0.001)$, hookah ( $7.6 \%$ vs. $2 \% ; p=0.001)$, cannabis smoking $(20.6 \%$ vs. $4.5 \% ; p=0.001)$ and alcohol consumption (22.3\% vs. 14.3\%; $p=0.019$ ). Amongst consumers, the prevalence of dependence or misuse was $45.3 \%$ for tobacco smoking, $56.7 \%$ for cannabis smoking and $44.5 \%$ for alcohol consumption. Fifty-two point five per cent had no toxic habit, $36.7 \%$ had one toxic habit, $9.9 \%$ two toxic habits, and $0.9 \%$ three toxic habits. The most frequent associations were tobacco-alcohol (6.5\%), and tobacco-cannabis (3\%).

Conclusions: Occupational health professionals have to play a key role in raising awareness and fighting against consumption of psychoactive substances amongst dockers.
\end{abstract}

(Int Marit Health 2018; 69, 2: 118-125)

Key words: psychoactive substances, dockers, addictions, poly-consumption

\section{INTRODUCTION}

The docking activity consists of loading and unloading container ships for import, export and transshipment and providing the sea/land connection of goods. These workers in the port facilities are exposed to significant psychosocial risks (stress, suffering at work, etc.) related to heavy organisational, environmental, physical, chemical constraints, etc. The work organisation requires dexterity

Dr. Chakib El Houssine Laraqui, Graduate School of Health Engineering, 24 rue Lafontaine, Quartier Racine, 20100 Casablanca, Morocco, e-mail: chlaraqui51@gmail.com 
and speed with vigilance and attention to avoid accidents of people and property. Working conditions outdoors (weather exposure) and/or at night amplify the frequency and severity of the risks to which dockers are exposed. Dockers exercise a profession with marked physical constraints, even if they resort to many devices for lifting and moving loads (gantry, self-propelled forklift truck, etc.). Operations carried out with these machines may entail different risks: vertebral stresses, vibrations, bruising trauma, crushing, falls, etc. In addition, some handling activities cannot be mechanised, exposing them to musculoskeletal disorders. The mechanical handling means can reduce some difficult handling activities but the operations are not without risk and represent serious dangers for dockers and workers nearby. The numerous chemical substances (fungicides, pesticides, fumigations, cement dust, hydrocarbon vapours, etc.) constitute a permanent and additional danger [1]. To what extent can these numerous occupational risks be at the origin of behaviour favouring the consumption of psychoactive substances? Amongst dockers, this collective consumption is part of the sociability of the group, is a support for the discussion and debate about their work and an element of distance from danger. The meaning given to the work "the real work for men", the mission, and the strength, and the professional culture (resistance to the effects of the consumption of psychoactive substances, etc.) characterise the job of the dockers. For them, the fear of the accident is averted by a very macho behaviour and a big denial of the risk [1].

The prevalence of toxic habits is constantly increasing in developing countries and all occupational sectors are affected [2-10]. All psychoactive substances cause a disorder of alertness, a change in the perception of risk and/or an increased risk-taking with consequences in terms of public health, occupational medicine, and safety at workplace [11]. Dockers are a particular target because the dangerousness and complexity of their work but no study has investigated the toxic habits amongst dockers in Morocco. The aim of this study was to determine the prevalence of the use and misuse of psychoactive substances amongst dockers, and to appreciate the poly-consumption according to socio-demographic and occupational characteristics.

\section{MATERIALS AND METHODS \\ SUBJECTS}

This epidemiological, observational and cross-sectional study was conducted in a great port of Morocco in 2015 and concerned 665 employees of a port company. All participants were male dockers and older than 20 years with length of employment above 1 year. The professional categories included 184 handlers and 481 machinery operators.

\section{QUESTIONNAIRE}

We used an individual questionnaire including sociodemographic characteristics (age, family status, educational level) and socioprofessional characteristics (professional categories, length of employment, working rhythm) and toxic habits (tobacco, cannabis, alcohol and others psychoactive substances: medicine and illegal drugs).

For tobacco smoking, we have individualised current smokers, former smokers and non-smokers. Subjects were categorised as current smokers if they smoked at the time of the survey or if they had stopped less than 3 months before the study and had smoked more than 100 cigarettes throughout their life. Former smokers were those who had stopped more than 3 months before the study and smoked more than 100 cigarettes throughout their life. Non-smokers are those who have never smoked or smoked less than 100 cigarettes throughout their life [12]. We quantified the consumption of tobacco in pack-years (number of packs smoked per day multiplied by the number of years of smoking).

The Fagerström test was used for the dependence assessment of tobacco smoking $[13,14]$. The items were summed to yield a total score of 0 to 10 . The ordering of dependence was very low (0 to 2$)$, low (3 to 4$)$, moderate (5 to 6$)$, high (7 to 8), and very high (9 to 10 ).

For cannabis smoking, in the same way, we have categorised our population to current consumers, former consumers and non-consumers. We quantified the consumption in calumets-years. Among cannabis smokers, we used the Cannabis Abuse Screening Test (CAST) [15, 16]. This test includes six items. To calculate a score, the responses were coded on a scale from 0 to 4 . The total score obtained could range from 0 to 24, and indicated whether or not the questioned users were at risk. A score less than 3 indicated no addiction risk, a score of 3 or less than 7 indicated low addiction risk, and a score of 7 or above indicated high addiction risk.

Alcohol consumption was quantified in number of standard drinks per day. A standard drink contains a fixed amount of pure alcohol, i.e. $10 \mathrm{~g}$. A standard drink is equivalent to $10 \mathrm{cl}$ of table wine at $12^{\circ}, 25 \mathrm{cl}$ of beer at $5^{\circ}$, $3 \mathrm{cl}$ of whisky at $40^{\circ}$, and $7 \mathrm{cl}$ of aperitif at $18^{\circ}$. Among drinkers, we have appreciated the risky consumption by the Alcohol Use Disorders Identification Test (AUDIT). This test is a 10-item screening tool developed by the World Health Organisation (WHO) to assess alcohol consumption, drinking behaviours, and alcohol-related problems. A score of 8 or more is considered to indicate hazardous or harmful alcohol use $[17,18]$. According to the WHO, risky consumption may cause serious harms in the medium to long term. For men it is more than 3 standard drinks per day or more than 21 standard drinks per week or more than 4 standard drinks per opportunity to drink. 
Table 1. Prevalence of toxic habits

\begin{tabular}{llll}
\hline Toxic habits $(\mathbf{n}=\mathbf{6 6 5})$ & No use & Former use & Current use \\
\hline Tobacco smoking & $325(48.9 \%)$ & $137(20.6 \%)$ & $203(30.5 \%)$ \\
Snuff tobacco & $596(89.6 \%)$ & $24(3.6 \%)$ & $45(6.8 \%)$ \\
Hookah & $622(93.5 \%)$ & $19(2.8 \%)$ & $24(3.7 \%)$ \\
Cannabis smoking & $517(77.7 \%)$ & $88(13.2 \%)$ & $60(9.1 \%)$ \\
Alcohol consumption & $348(52.4 \%)$ & $207(31.1 \%)$ & $110(16.5 \%)$ \\
Others psychotropic substances & $601(90.3 \%)$ & $43(6.5 \%)$ & $21(3.2 \%)$
\end{tabular}

We defined the use as a moderate or occasional consumption with a low risk to health, and the misuse is a consumption that may cause physical, social and/or psychological troubles. The misuse includes hazardous or spot abuse, harmful or repeated abuse and addiction. We considered misuses as:

- dependent cigarette smokers with a Fagerström test score greater than or equal to 5 ;

- addiction cannabis smokers with a CAST score greater than 7 ;

- hazardous or harmful alcohol consumption with AUDIT test score greater than or equal to 8 or meeting the WHO criteria's (more than 21 glasses per week or more than 4 glasses per opportunity to drink).

\section{PROCEDURE OF THE STUDY}

We previously contacted the occupational physician to explain the purpose of the study and obtain his support. The interviews, with full respect of the confidentiality, took place at the occupational health service and lasted between 15 and 20 minutes for each person. The dockers answered to the questionnaire without difficulty and with enthusiasm.

\section{STATISTICAL ANALYSIS}

The statistical analyses were performed using the SPSS version 11.5 software package. The differences between groups were compared using t tests for continuous variables and $\chi^{2}$ tests for categorical ones. The statistical level of significance was established at $5 \%$. For a proportion, we calculate the lower and upper limits of the $95 \%$ confidence intervals $(\mathrm{Cl})$.

\section{RESULTS DEMOGRAPHIC AND OCCUPATIONAL CHARACTERISTICS OF DOCKERS}

The average age of total population was $43.1 \pm 7.8$ years (range 20-60 years). Ninety one point seven per cent were living in couple. Three point four per cent were illiterate, $19.4 \%$ had attended primary school, $42.2 \%$ secondary school, and $34.3 \%$ college or university. The average length of employment was $18.2 \pm 5.1$ years.

\section{PREVALENCE OF TOXIC HABITS}

The prevalence of harmful habits was $30.5 \%(95 \% \mathrm{Cl}$ 27-34) for tobacco smoking, 6.8\% (95\% Cl 4.9-8.7) for the snuff tobacco, 3.7\% (95\% Cl 2.3-5.1) for hookah, 9.1\% (95\% Cl 6.9-11.2) for cannabis smoking, 16.5\% (95\% Cl 13.7-19.3) for alcohol consumption, and 3.2\% (95\% Cl 1.9-4.5) for others psychotropic substances.

The average age of onset of tobacco smoking was $14.3 \pm$ \pm 2.1 years $(95 \% \mathrm{Cl} 14.1-14.5)$, cannabis smoking $18.3 \pm$ \pm 4.5 years $(95 \% \mathrm{Cl} 17.9-18.6)$, alcohol consumption $18.8 \pm$ \pm 3.1 years $(95 \% \mathrm{Cl} 18.5-19)$, tobacco sniffing $24.5 \pm 4.9$ years (95\% Cl 24.1-24.9), hookah $22.5 \pm 3.9$ years (95\% Cl 22.2-22.8), and others consummated psychotropic substances $26.2 \pm 4.1$ years $(95 \% \mathrm{Cl} 25.9-26.5)$.

The average daily of tobacco smoking was $15.8 \pm 5.7$ cigarettes, of hookah $2.1 \pm 0.7$, of snuff tobacco $12 \pm 3.9$ snuffs, of cannabis smoking $8.1 \pm 2.9$ calumets, and of alcohol consumption $4.3 \pm 1.8$ drinks.

The harmfulness of tobacco smoking to health was known by $97.4 \%$ of dockers, alcohol consumption by $94 \%$, and cannabis smoking by $86 \%$, snuff tobacco by $57 \%$ and hookah by only $56.8 \%$. Seventy three point one per cent of tobacco sniffers were former cigarettes smokers. The hookah was considered safer for health than cigarettes by $49.5 \%$ of consumers who consider that dangerous substances smoked are filtered by water.

Attempts at weaning longer than 2 days of abstinence were made by $59.1 \%$ of tobacco smokers, $72.6 \%$ of alcohol drinkers, $74 \%$ of cannabis smokers, $68 \%$ of hookah smokers and $44.1 \%$ of tobacco sniffers (Table 1 ).

\section{THE ASSOCIATION BETWEEN SOCIODEMO- GRAPHIC CHARACTERISTICS AND TOXIC HABITS}

The prevalence of tobacco smoking (31.3\% vs. 30.4\%; $p=0.947$ ) and other psychotropic substances (4\% vs. $3 \% ; p=0.816$ ) was not significantly higher among people under 40 years old. The frequency of cannabis smoking $(26.3 \%$ vs. $6 \% ; p=0.001)$, hookah $(17.2 \%$ vs. $1.2 \%$; $p=0.0001)$ and alcohol consumption (35.4\% vs. $13.3 \%$; $p=0.0001$ ) was significantly higher among subjects under 
Table 2. Association between sociodemographic characteristics and toxic habits

\begin{tabular}{|c|c|c|c|c|c|c|c|}
\hline SDC & $N=665$ & $\begin{array}{l}\text { TS } \\
203(30.5 \%)\end{array}$ & $\begin{array}{l}\text { ST } \\
45(6.8 \%)\end{array}$ & $\begin{array}{l}\text { H } \\
24(3.7 \%)\end{array}$ & $\begin{array}{l}\text { CS } \\
60(9.1 \%)\end{array}$ & $\begin{array}{l}\text { AC } \\
110(16.5 \%)\end{array}$ & $\begin{array}{l}\text { OPS } \\
21(3.2 \%)\end{array}$ \\
\hline \multicolumn{8}{|l|}{ Age [years]: } \\
\hline$\leq 30$ & 21 (3.2\%) & $6(28.5 \%)$ & $1(4.8 \%)$ & $8(38.1 \%)$ & $10(47.6 \%)$ & 9 (42.8\%) & $1(4.8 \%)$ \\
\hline $31-40$ & 78 (11.7\%) & 25 (32.1\%) & 3 (3.8\%) & 9 (11.5\%) & 16 (20.5\%) & 26 (33.3\%) & 3 (3.8\%) \\
\hline $41-50$ & 332 (49.9\%) & $89(26.8 \%)$ & $22(6.6 \%)$ & $4(1.2 \%)$ & 20 (6\%) & $43(13 \%)$ & $10(3 \%)$ \\
\hline$>50$ & 234 (35.2\%) & 83 (35.4\%) & 19 (8.1\%) & 3 (1.3\%) & $14(6 \%)$ & 32 (16.7\%) & 7 (3\%) \\
\hline$<40$ & 99 (14.9\%) & 31 (31.3\%) & $4(4 \%)$ & 17 (17.2\%) & $26(26.3 \%)$ & 35 (35.4\%) & $4(4 \%)$ \\
\hline$\geq 40$ & $566(85.1 \%)$ & $172(30.4 \%)$ & $41(7.2 \%)$ & $7(1.2 \%)$ & 34 (6\%) & 75 (13.3\%) & $17(3 \%)$ \\
\hline$p$ & $<0.001$ & 0.947 & 0.340 & $<0.001$ & $<0.001$ & $<0.001$ & 0.816 \\
\hline \multicolumn{8}{|l|}{ Family status: } \\
\hline Living alone & 55 (8.3\%) & 25 (45.4\%) & 9 (16.3\%) & $10(18.2 \%)$ & $21(38.2 \%)$ & 42 (76.3\%) & $4(7.2 \%)$ \\
\hline Living in a couple & $610(91.7 \%)$ & $178(29.2 \%)$ & 36 (5.9\%) & $14(2.3 \%)$ & 39 (6.4\%) & 68 (11.1\%) & $17(2.8 \%)$ \\
\hline$p$ & $<0.001$ & 0.018 & 0.007 & $<0.001$ & $<0.001$ & $<0.001$ & 0.156 \\
\hline \multicolumn{8}{|l|}{ Educational level: } \\
\hline Illiterate & $23(3.4 \%)$ & $12(52.2 \%)$ & $8(34.8 \%)$ & $4(17.4)$ & $11(47.8 \%)$ & $12(52.5 \%)$ & $0(0 \%)$ \\
\hline Primary & $129(19.4 \%)$ & 62 (48.1\%) & $19(14.7 \%)$ & $10(7.7 \%)$ & 25 (19.4\%) & $23(17.8 \%)$ & $4(3.1 \%)$ \\
\hline Secondary & 285 (42.9\%) & 84 (29.5\%) & $14(4.9 \%)$ & $10(3.5 \%)$ & $20(7 \%)$ & $40(14 \%)$ & $5(1.8 \%)$ \\
\hline Superior & 228 (34.3\%) & 45 (19.7\%) & $4(1.8 \%)$ & $0(0 \%)$ & $4(1.7 \%)$ & 35 (15.3\%) & $12(5.3 \%)$ \\
\hline $\mathrm{p}$ & $<0.001$ & $<0.001$ & $<0.001$ & $<0.001$ & $<0.001$ & $<0.001$ & 0.154 \\
\hline
\end{tabular}

AC - alcohol consumption; CS - cannabis smoking; H - hookah; OPS - other psychotropic substances; SPC - socioprofessional characteristics; ST - snuff tobacco; TS - tobacco smoking

Table 3. Association between socioprofessional characteristics and toxic habits

\begin{tabular}{|c|c|c|c|c|c|c|c|}
\hline SPC & $N=665$ & $\begin{array}{l}\text { TS } \\
203(30.5 \%)\end{array}$ & $\begin{array}{l}\text { ST } \\
45(6.8 \%)\end{array}$ & $\begin{array}{l}\text { H } \\
24(3.7 \%)\end{array}$ & $\begin{array}{l}\text { CS } \\
60(9.1 \%)\end{array}$ & $\begin{array}{l}\text { AC } \\
110(16.5 \%)\end{array}$ & $\begin{array}{l}\text { OPS } \\
21(3.2 \%)\end{array}$ \\
\hline \multicolumn{8}{|c|}{ Professional categories: } \\
\hline Machinery operators & $481(72.3 \%)$ & $130(27 \%)$ & $22(4.6 \%)$ & $10(2)$ & $22(4.5)$ & $69(14.3)$ & $17(3.5)$ \\
\hline Handlers & $184(27.7 \%)$ & $73(39.7 \%)$ & 23 (12.5\%) & $14(7.6 \%)$ & $38(20.6 \%)$ & $41(22.3 \%)$ & $4(2.2 \%)$ \\
\hline $\mathrm{p}$ & $<0.001$ & 0.002 & $<0.001$ & 0.001 & $<0.001$ & 0.019 & 0.516 \\
\hline \multicolumn{8}{|c|}{ Length of employment [years]: } \\
\hline$\leq 5$ & $20(3 \%)$ & $6(30 \%)$ & $1(5 \%)$ & $5(25 \%)$ & $10(50 \%)$ & $15(75 \%)$ & $0(0 \%)$ \\
\hline $6-15$ & $88(13.2 \%)$ & $47(53.4 \%)$ & $3(3.4 \%)$ & $6(6.8 \%)$ & $13(14.8 \%)$ & $24(27.2 \%)$ & $4(4.5 \%)$ \\
\hline$>15$ & $557(83.8 \%)$ & $150(26.9 \%)$ & $41(7.4 \%)$ & $13(2.3 \%)$ & $37(6.6 \%)$ & $71(12.7 \%)$ & $17(3 \%)$ \\
\hline$p$ & $<0.001$ & $<0.001$ & 0.371 & $<0.001$ & $<0.001$ & $<0.001$ & 0.542 \\
\hline \multicolumn{8}{|l|}{ Working rhythm: } \\
\hline Typical & $161(24.2 \%)$ & $35(21.7 \%)$ & $10(6.2 \%)$ & $5(3.1 \%)$ & $9(5.6 \%)$ & $28(17.4 \%)$ & $8(5 \%)$ \\
\hline Atypical & $504(75.8 \%)$ & $168(33.3 \%)$ & 35 (6.9\%) & $19(3.8 \%)$ & $51(10.1 \%)$ & 82 (16.3\%) & $13(2.6 \%)$ \\
\hline$p$ & $<0.001$ & 0.007 & 0.887 & 0.88 & 0.112 & 0.832 & 0.211 \\
\hline
\end{tabular}

AC - alcohol consumption; CS - cannabis smoking; H - hookah; OPS - other psychotropic substances; SPC - socioprofessional characteristics; ST - snuff tobacco; TS - tobacco smoking

40 years old. The prevalence of snuff tobacco (7.2\% vs. $4 \% ; p=0.340$ ) was higher, but not significantly, among people over 40 years old.

The prevalence of toxic habits was significantly higher among people living alone except for other psychotropic substances. The prevalence of consumption of psychoactive substance is significantly and inversely proportional to educational level except for other psychotropic substances.

The average age of tobacco smokers was $47.3 \pm 6.9$ years, hookah smokers $35.8 \pm 6,6$ years, tobacco sniffers $48.1 \pm 7,5$ years, cannabis smokers $42.2 \pm 9$ years, alcohol consumers $43.9 \pm 8.6$ years and others psychotropic substances users $45.9 \pm 7.7$ years (Table 2 ).

\section{ASSOCIATION BETWEEN SOCIO-PROFESSIONAL CHARACTERISTICS AND TOXIC HABITS}

The average length of employment for the total population was $18.1 \pm 4.1$ years, for cigarette smokers was $17.1 \pm 3.9$ years, hookah smokers $13.8 \pm 2.7$ years, tobacco sniffers $18,9 \pm 3.8$ years, cannabis smokers $14.9 \pm 4.2$ years, alcohol consumers of $15.4 \pm 3.1$ years and others psychotropic substances consumers $18.1 \pm 4.4$ years. The prevalence of toxic habits was significantly higher in handlers than among machinery operators: tobacco smoking (39.7\% vs. $27 \%$; $p=0.002)$, snuff tobacco ( $12.5 \%$ vs. $4.6 \%$; $p=0.001)$, hookah $(7.6 \%$ vs. $2 \%$; $p=0.001)$, cannabis smoking (20.6\% vs. $4.5 \% ; p=0.001)$ and alcohol consumption (22.3\% vs. 14.3\%; $p=0.019$ ) (Table 3 ). 
Table 4. Association between sociodemographic characteristics and misuse (dependence)

\begin{tabular}{llll}
\hline $\begin{array}{l}\text { Sociodemographic } \\
\text { characteristics }\end{array}$ & $\begin{array}{l}\text { Tobacco smoking } \\
\mathbf{9 2 / 2 0 3}(\mathbf{4 5 . 3} \%)\end{array}$ & $\begin{array}{l}\text { Cannabis smoking } \\
\mathbf{3 4 / 6 0} \mathbf{5 6 . 7 \% )}\end{array}$ & $\begin{array}{l}\text { Alcohol consumption } \\
\mathbf{4 9 / 1 1 0 ~ ( 4 4 . 5 \% )}\end{array}$ \\
\hline $\begin{array}{l}\text { Age [years]: } \\
\leq 30\end{array}$ & & & \\
$31-40$ & $3 / 6(50 \%)$ & $3 / 10(30 \%)$ & $3 / 9(33.3 \%)$ \\
$41-50$ & $7 / 15(46.7 \%)$ & $15 / 16(37.5 \%)$ & $15 / 26(57.7 \%)$ \\
$>50$ & $43 / 89(48.3 \%)$ & $10 / 20(75 \%)$ & $11 / 32(46.5 \%)$ \\
$<40$ & $39 / 83(47 \%)$ & $9 / 26(34.6 \%)$ & $18 / 35(51.4 \%)$ \\
$\geq 40$ & $10 / 31(32.3 \%)$ & $25 / 34(73.5 \%)$ & $32 / 75(42.7 \%)$ \\
p & $82 / 172(47.7 \%)$ & 0.006 & 0.513 \\
Family status: & 0.164 & & \\
Living alone & & $14 / 21(66.6 \%)$ & $19 / 42(45.2 \%)$ \\
Living in a couple & $14 / 25(56 \%)$ & $20 / 39(51.2 \%)$ & $30 / 68(44.1 \%)$ \\
p & $78 / 178(43.8 \%)$ & 0.382 & 0.934 \\
Educational level: & 0.352 & & \\
llliterate & & $7 / 11(63.3 \%)$ & $9 / 12(75 \%)$ \\
Primary & $8 / 12(66.7 \%)$ & $18 / 25(72 \%)$ & $14 / 23(61 \%)$ \\
Secondary & $25 / 62(40.3 \%)$ & $9 / 20(45 \%)$ & $22 / 40(55 \%)$ \\
Superior & $39 / 84(46.4 \%)$ & $0 / 4(0 \%)$ & $4 / 35(11.4 \%)$ \\
p & $20 / 45(44.4 \%)$ & 0.146 & 0.011
\end{tabular}

Table 5. Association between socio-professional characteristics and misuse or dependence

\begin{tabular}{llll}
\hline Socio-professional characteristics & $\begin{array}{l}\text { Tobacco smoking } \\
\mathbf{9 2 / 2 0 3}(\mathbf{4 5 . 3} \%)\end{array}$ & $\begin{array}{l}\text { Cannabis smoking } \\
\mathbf{3 4 / 6 0}(\mathbf{5 6 . 7 \% )}\end{array}$ & $\begin{array}{l}\text { Alcohol consumption } \\
\mathbf{4 9 / 1 1 0}(\mathbf{4 4 . 5} \%)\end{array}$ \\
\hline $\begin{array}{l}\text { Professional categories: } \\
\text { Machinery operators }\end{array}$ & $50 / 130(40 \%)$ & $9 / 22(40.9 \%)$ & $20 / 69(28.9 \%)$ \\
Handlers & $42 / 73(61.8 \%)$ & $25 / 38(65.8 \%)$ & $21 / 41(70.7 \%)$ \\
p & 0.013 & 0.109 & 0.033 \\
Length of employment [years]: & & & $7 / 15(46.7 \%)$ \\
$\leq 5$ & $2 / 6(33.3 \%)$ & $5 / 10(50 \%)$ & $13 / 24(54.2 \%)$ \\
$6-15$ & $22 / 47(46.8 \%)$ & $8 / 13(61.5 \%)$ & $29 / 71(40.8 \%)$ \\
$>15$ & $68 / 150(45.3 \%)$ & $21 / 37(56.7)$ & 0.517 \\
p & 0.823 & 0.858 & $11 / 28(39.3 \%)$ \\
Working rhythm & & & $38 / 82(46.3 \%)$ \\
Typical & $13 / 35(37.1 \%)$ & $4 / 9(44.4 \%)$ & 0.668 \\
Atypical & $80 / 168(47.6 \%)$ & $30 / 51(58.8 \%)$ & 0.662 \\
p & 0.345 & &
\end{tabular}

\section{ASSOCIATION BETWEEN SOCIODEMOGRAPHIC CHARACTERISTICS AND MISUSE}

The average age, of people who misuse, was $47.7 \pm 6.9$ years for tobacco smokers, $44 \pm 6.5$ years among cannabis smokers and $42.6 \pm 7.7$ years at alcohol consumers.

The misuse was more frequent in people over 40 years old for tobacco smoking ( $47.7 \%$ vs. $32.3 \%$; $p=0.164$ ) but not significantly. The misuse was significantly more frequent in people above 40 years old for cannabis smoking $(73.5 \%$ vs. $34.6 \% ; p=0.006)$. The misuse of alcohol was more frequent, but not significantly, among those under 40 years old (51.4\% vs. $42.7 \%$; $p=0.513)$.

For the all toxic habits, the misuse was more frequent, but not significantly, in people living alone: tobacco smoking ( $56 \%$ vs. $43.8 \%$; $p=0.352$ ), cannabis smoking $(66.6 \%$ vs. $51.2 \% ; p=0.382)$, and alcohol consumption (45.2\% vs. 44.1\%; $p=0.934)$.
The misuse was significantly more frequent among illiterate people for tobacco smoking ( $66.7 \%$ vs. $44 \%$; $p=0.021$ ) and alcohol consumption ( $75 \%$ vs. $40.8 \%$; $p=0.011$ ). For cannabis smoking ( $63.3 \%$ vs. $55.1 \%$; $p=0.146)$, the difference was not significant (Table 4).

\section{ASSOCIATION BETWEEN SOCIO-PROFESSIONAL CHARACTERISTICS AND MISUSE}

The average length of employment of people with misuse was $15.3 \pm 3.8$ years for cigarette smokers, $14.4 \pm 3.9$ years for cannabis smokers and $14.1 \pm 4.1$ for alcohol consumers.

For tobacco smokers, misuse was significantly more important among handlers than machinery operators (61.8\% vs. $40 \%$; $p=0.013)$, and alcohol consumers $(70.7 \%$ vs. $28.9 \%$; $p=0.033)$. The difference was not significant for the cannabis smokers (65.8\% vs. 40.9\%; $p=0.109$ ). The difference was not significant for length of employment and rhythm at work(Table5). 
Table 6. Prevalence of toxic habits and their associations

\begin{tabular}{lll}
\hline Toxic habits & Toxic substances & $\mathbf{6 6 5 ( 1 0 0 \% )}$ \\
\hline 0 toxic habit & - & $349(52.5 \%)$ \\
1 toxic habit & TS & $131(19.7 \%)$ \\
$-244(36.7 \%)$ & CS & $34(5.1 \%)$ \\
& AC & $61(9.2 \%)$ \\
& OPS & $18(2.7 \%)$ \\
2 toxic habits & TS + CS & $20(3 \%)$ \\
$-66(9.9 \%)$ & TS + AC & $43(6.5 \%)$ \\
& TS + OPS & $3(0.4 \%)$ \\
3 toxic habits & TS + CS + AC & $6(0.9 \%)$ \\
-6 (0.9\%) & & \\
AC - alcohol consumption; CS - cannabis smoking; OPS - other psychotropic \\
substances; TS - tobacco smoking
\end{tabular}

\section{PREVALENCE OF TOXIC HABITS ASSOCIATIONS}

Only 349 (52.5\%) people did not have any toxic habit, $36.7 \%$ had one toxic habit, $9.9 \%$ two toxic habits, and $0.9 \%$ three toxic habits. The most frequent associations were tobacco-alcohol (6.5\%), and tobacco-cannabis (3\%) (Table 6).

\section{DISCUSSION}

The significant increase in the frequency of consumption of psychoactive substances is a source of apprehension and concern, particularly in developing countries [2]. In 2014, the Moroccan National Observatory for Drugs and Addictions (observatoire national des drogues et des additions) reported that the prevalences of tobacco smoking, cannabis consumption and alcohol consumption among Moroccan male population in general aged over 20 were 34.5\%, 9\%, and $14 \%$, respectively [3]. In the same population, a study conducted by the Ministry of Health reported that the prevalence of tobacco smokers was $32 \%$ and alcohol consumers was $23.4 \%$ [4]. In our study, the prevalence of these harmful habits was $30.5 \%$ for tobacco smoking, $9.1 \%$ for cannabis smoking, and $16.5 \%$ for alcohol consumption. Nevertheless, the prevalence was significantly higher among handlers than machinery operators: for tobacco smoking (39.7\% vs. $27 \%$; $p=0.002)$, for cannabis smoking $(20.6 \%$ vs. $4.5 \%$; $p<0.0001)$, and for alcohol consumption (22.3\% vs. $14.3 \%$; $p=0.019)$. The prevalence among handlers was as high as in administrative staff on land working in the maritime sector: $39.5 \%$ for tobacco smoking, $15.5 \%$ for cannabis, and $28.6 \%$ for alcohol. They were significantly lower than among Moroccan fishermen [10]. Three studies conducted in this population in 2014, 2016 and 2017 showed 58.8\%, $52.3 \%$ and $46.6 \%$ for tobacco smoking respectively, $36.2 \%$, $31.7 \%$ and $37.4 \%$ for cannabis smoking and $36.5 \%, 38.9 \%$ and $42.5 \%$ for alcohol consumption. According to the National Institute of Prevention and Education for Health (Institut National de Prévention et d'Education pour la Santé,
France), the fishery sector was ranked at the first place of consumption of toxic substances: there were $63.1 \%$ tobacco smokers, $14.5 \%$ hazardous drinkers and 3.4\% had smoked cannabis in the previous month. Seafarers would smoke higher than the general population for several reasons related to hard, rough and very stressful working conditions [19].

In our study, $36.7 \%$ of dockers had one toxic habit, $9.9 \%$ two, and $0.9 \%$ three. The most frequent associations were tobacco-alcohol (6.5\%), and tobacco-cannabis (3\%). Among fishermen, $56.4 \%$ had one toxic habit, $20.4 \%$ two, and $11.9 \%$ three. The most frequent associations were tobacco-cannabis (10.5\%) and tobacco-alcohol (6.1\%). According to the National Institute of Prevention and Education for Health (Institut National de Prévention et d'Education pour la Santé, France), regular poly-consumption concerned $8.3 \%$ of the adult population. The most common combinations were alcohol-tobacco (5.9\%), tobacco-cannabis (1.6\%) and alcohol-tobacco-cannabis (0.7\%) [19-22]. In our study, 45.3\% of tobacco smokers, $56.7 \%$ of cannabis smokers and $44.5 \%$ of alcohol consumers had an addiction. Among fishermen, the prevalence was $49.5 \%$ for tobacco smoking, $61.2 \%$ for cannabis smoking and $52.1 \%$ for alcohol consumption [5]. These frequencies were higher than in the Moroccan general population, with $2 \%$ of alcohol abuse, $3.3 \%$ of toxic substances abuse and $2.8 \%$ of misuse of toxic substances [3]. In our survey, the harmfulness to the health of tobacco smoking was known by $97.4 \%$, of alcohol consumption by $94 \%$, and of cannabis smoking by $86 \%$, of snuff tobacco by $57 \%$ and of hookah by $56.8 \%$. Seventy three point one per cent of tobacco sniffers were former cigarettes smokers. The harmfulness of alcohol consumption was known by $92 \%$ of fishermen [5]. Only $7 \%$ of Scottish harbourmen considered their level of consumption as harmful to their health [23]. Cannabis is the illicit drug most used in the world $[11,16]$. Socio-geographical, economic and cultural factors play an important role in its consumption. Cannabis is highly consumed in Morocco because it is cheaper than manufactured cigarettes [24]. The hookah was considered safer to the health than cigarettes by $49.5 \%$ of consumers. Water pipe is known under different names in parts of the world: hookah, narghile, shisha or goza. It is now the object of a renewed interest because its use has been spreading very fast among young people in Western countries and in Morocco. The number of bars and establishments where the water pipe can be smoked is increasing and almost are attended by mostly young people. The arguments they use for justifying water pipe smoking are the "natural" nature, health and safety aspect of the product, its fruity flavours (apple, strawberry, etc.), the sharing of the dose enhancing a sense of community belonging, the novelty of the product, and a distinction from the smoking habits of adults. The conviction that, water acting as a filter, this way of smoking 
tobacco is less dangerous than cigarette smoking. The recent craze for hookah is due to the mental representation of the mode of use as being healthier and friendlier than cigarettes [25, 26]. In Morocco, the prevalence of its use in the general population in 2010 was $4.9 \%$ lower than in Tunisia (5.8\%) and in Syria $(19.7 \%)[5,25,26]$. In our study, the prevalence of toxic habits was higher in people with a low educational level except for other psychotropic substances. A survey in the Moroccan population [12] showed that the prevalence of tobacco smoking was inversely associated with the level of education among men; thus, the risk was higher among illiterate men than those whose level of education was academic. Some working constraints increase alcohol consumption: outdoor work (more than half of working time), work in painful or tiring posture, exposure to shaking or vibration, carrying heavy loads, long trips or exhausting or fast [27]. Work stress appears as a possible risk factor exposing to toxic habits. At the seaside, the stress is caused by high psychological demands, low decision latitude and inadequate professional support, and compounded by difficult and dangerous working conditions [28]. According to the National Institute of Prevention and Education for Health (Institut National de Prévention et d'Education pour la Santé, France) [19-22], $36.2 \%$ of regular tobacco smokers, $9.3 \%$ of alcohol users and $13.2 \%$ of cannabis users said they had increased their consumption due to problems related to their work over the pasted 12 months. However, these results should not obscure the fact that the professional activity globally remains a protection factor of addictive behaviour, compared to an unemployment situation [29, 30].

The consumption of psychoactive substances is an alarming problem of public health and occupational safety. It has an impact on professional and social life and in case of accident, the machinery operators and their companies held responsible. Several legal texts about the fight against the consumption of addictive substances exist in Morocco. The physical and mental fitness of the professional drivers has a twofold appreciation in Law 65-99 of the Labour Code, in Law 52-05 of the Traffic Code and in their application texts [31, 32]. Like all workers, dockers are subject to occupational health Laws (Articles 304-341 of the Labour Code) and must undergo a medical examination for fitness for work by an occupational physician. In addition, every 2 years, they must consult a doctor approved by the Ministry of Health (Article 14 of the Traffic Code) to obtain a medical certificate of driving fitness for the renewal of the driving license. The prevention of addictive behaviour and its penalties are detailed in the Law related to the Traffic Code, the Penal Code and the Law related to the Commerce, Detention and Use of Poisonous Substances [33]. This latter Law combines the medical care of the consumers and the judicial repression of the dealers. Articles 39-42 of the Traffic Code compel professional drivers to receive ongoing formation from approved establishments. Article 177 deals with screening and criminal sanctions for driving under the influence of alcohol, narcotics or some medications that are contraindicated while driving.

\section{LIMITATIONS OF THE STUDY}

Our study presents two main limitations. Our survey was cross-sectional, the healthy worker effect could create a selection bias. The weak points of self-reporting must be underlined especially for the consumption of psychoactive substances mainly for alcohol. The prevalence of alcohol use was probably underestimated because the Muslim religion of our subjects prohibits its consumption and the related issues remain taboo. There was no solution to avoid or limit individual variation in self-reporting. The target was a global quantification and approach. However, this study can be considered a faithful representation of the situation in this sector in Morocco.

\section{CONCLUSIONS}

Among the dockers, the handlers are a population at high risk of consumption of psychoactive substances. Collective and individual communications and actions must be conducted amongst this group. The occupational health physicians have to play a key role in the development and implementation of the preventive approach. The support and specialised care facilities must be available to ensure individual attention and early treatment when necessary.

\section{REFERENCES}

1. Jensen E. Quelle sécurité pour les dockers ? Santé et Sécurité Septembre / Octobre 2014 ; N54. http://www.agir-mag.com/santesecurite-quelle-securite-au-travail-pour-les-dockers.html.

2. OMS. Usage de substances psychoactives et dépendance. Document technique. EM/RC52/5 Septembre 2005; 17 p. http://www. em-consulte.com/rmr/article/1101092.

3. Jalal T, El Omari F, Sabir M. Rapport annuel de l'Observatoire national des drogues et addictions. Maroc, Rapport officiel 2014:108 p. www.onda-drogues.com.

4. Ministère de la santé au Maroc. Enquête sur la santé et la réactivité du système de santé au Maroc 2003; oct. 2007; 128p. file:///C:/ Users/Administrateur/Downloads/ESRSSM 2003\%20(2).pdf 2003.

5. Laraqui O, Laraqui S, Manar N, et al. Prevalence of consumption of addictive substances amongst Moroccan fishermen. Int Marit Health. 2017; 68(1): 19-25, doi: 10.5603/IMH.2017.0004, indexed in Pubmed: 28357832.

6. Chemsi M, Rbai M, Echchachoui H, et al. Epidemiology of addictive behaviors among civilian air crew in Morocco. Med Aéronautique et Spatial. 2009; 187: 25-29.

7. Laraqui O, Laraqui S, Manar N, Ghailan T, Deschamps F, Laraqui $\mathrm{CH}$. Prevalence of consumption of addictive substances amongst taxi drivers. 2018 Medicine del Lavoro [in press].

8. Laraqui O, Laarej H, Manar N, et al. Dépistage de la bronchopneumopathie chronique obstructive en milieu professionnel au Maroc 
à propos d'une étude multicentrique. Revue des Maladies Respiratoires. 2017; 34: A170, doi: 10.1016/j.rmr.2016.10.403.

9. Loriol M. Les réponses individuelles et collectives à la souffrance au travail. Congrès les conduites dopantes au travail - 16 septembre 2010 - Lausanne (Suisse); 17 p. http://www.alcoolautravail.ch/ sites/default/files/PDF/Congres-2010/05-Marc-Loriol.pdf.

10. Laraqui $\mathrm{O}$, Laraqui S, Manar N, et al. Risk-taking behaviours among fishermen in Morocco by the evaluation of. Int Marit Health. 2017; 68(2): 83-89, doi:10.5603/IMH.2017.0016, indexed in Pubmed: 28660610.

11. Durand E, Gayet C, Laborde L, Van Deweerd C, Farges E. Conduites addictives et travail. INRS. DMT 2008; 115: 339-362 2008.

12. El Rhazi K, Nejjari C, Berraho M, et al. Inequalities in smoking profiles in Morocco: the role of educational level. Int J Tuberc Lung Dis. 2008; 12(11): 1327-1332, indexed in Pubmed: 18926045.

13. Fagerström KO. Measuring degree of physical dependence to tobacco smoking with reference to individualization of treatment. Addict Behav. 1978; 3(3-4): 235-241, indexed in Pubmed: 735910.

14. Underner M, Houezec JLe, Perriot J, et al. Les tests d'évaluation de la dépendance tabagique. Revue des Maladies Respiratoires. 2012; 29(4): 462-474, doi: 10.1016/j.rmr.2011.09.051.

15. Institut national de prévention et d'éducation pour la santé (INPES). Repérage précoce de l'usage nocif du cannabis 2006; 4 p. http:// inpes.santepubliquefrance.fr/ CFESBases/catalogue/pdf/982.pdf.

16. Gyepesi A, Urban R, Farkas J. Psychometric properties of the Cannabis Abuse Screening. Test in Hungarian samples of adolescents and young adults. Eur Addict Res. 2014; 20(3): 119-128.

17. Demortiere G, Pessione F, Batel P. Problèmes liés à l'alcool en médecine de travail. Dépistage par l'utilisation d'auto-questionnaires: intérêt, faisabilité, limites. INRS, DMT. 2001; 85: 193-200.

18. Yersin B. Les questionnaires de dépistage en alcoologie. Alcoologie. 1999; 21(3): 397-401.

19. Institut National de Prévention et d'Education pour la Santé (INPES, France): National Institute of Prevention and Education for Health. Baromètre santé 2010 des substances psychoactives plus consommées dans certains secteurs de travail. http://www.inpes. sante.fr/Barometres/barometre-sante-2010/pdf/resultats-barometres-spa.pdf.

20. Goullé JP, Morel F. Addictions en milieu professionnel. Académie nationale de médecine, Paris. Rapport 10 octobre 2017. http. www.academie-medecine.frarticles-du-bulletinpublicationidpublication $=100768$.

21. Palle $\mathrm{C}$. Synthèse de la revue de littérature sur les consommations de substances psychoactives en milieu professionnel. Observatoire français des drogues et toxicomanies, octobre 2015, 13p. https:// www.ofdt.fr/publications/collections/notes/synthese-revue-de-litterature-addictions-en-milieu-professionnel/.

22. Eloy A, Cherbonnet Guillouët $\mathrm{C}$, Leclerc C. Observatoire régional de la santé du Centre. Consommation de produits psychoactifs en milieu de travail 2014; 164 p. http://www.loiret.gouv.fr/content/ download/16629/112126/file/Rapport\%20Produits\%20psychoactifs\%20travail\%20Centre\%200RS.pdf.

23. Frantzeskou $E$, Jensen 0 , Linos A. Prevalence of health risk factors among fishermen: a review. Occupational Medicine Health Affairs. 2014; 2(2): 157, doi: 10.4172/2329-6879.1000157.

24. Manoudi F, Boutabia S, Asri F, et al. Approche épidémiologique de la toxicomanie en milieu universitaire à Marrakech (Maroc). Annales Médico-psychologiques, revue psychiatrique. 2010; 168(9): 698-701, doi: 10.1016/j.amp.2010.09.003.

25. Kiter G, Uçan ES, Ceylan E, et al. Water-pipe smoking and pulmonary functions. Respir Med. 2000; 94(9): 891-894, doi: 10.1053/ rmed.2000.0859, indexed in Pubmed: 11001082.

26. Chaouachi K. Tout savoir sur le Narguilé: société, culture, histoire et santé. Maisonneuve Et Larose. 2007: 256.

27. Organisation mondiale de la santé. Neurosciences: usage de substance psychoactives et dépendance.2004;40p.ttp://www.who.int/ substance_abuse/publications/en/Neuroscience_F.pdf.

28. Pougnet R, Pougnet L, Loddé B, et al. Consumption of addictive substances in mariners. Int Marit Health. 2014; 65(4): 199-204, doi:10.5603/IMH.2014.0038, indexed in Pubmed: 25522703.

29. Orset C, Sarazin M, Cabal C. Les conduites addictives en milieu professionnel. Archives des Maladies Professionnelles et de l'Environnement. 2007; 68(1): 5-19, doi: 10.1016/s1775-8785(07)88863-1.

30. Niezborala M, Boeuf-Cazou O, Lapeyre-Mestre M, et al. Profil de consommation de substances psychoactives dans le milieu du travail: résultats de l'enquête Mode de Vie et Travail. Archives des Maladies Professionnelles et de l'Environnement. 2012; 73(3): 492, doi: 10.1016/j.admp.2012.03.272.

31. Loi $n{ }^{\circ} 65-99$ relative au code du travail promulguée par le dahir $n^{\circ}$ 1-03-194 du 11 septembre 2003 et publiée au bulletin officiel $n^{\circ}$ 5210 du 6 mai 2004, p.600-658. http://www.ilo.org/dyn/natlex/ docs/SERIAL/67319/64073/F518847737/MAR67319.pdf.

32. Loi ${ }^{\circ} 52-05$ relative au code de la route promulguée par le dahir $n^{\circ}$ 1-10-07 du 11 février 2010 et publiée au bulletin officiel $n^{\circ} 5874$ du 16 septembre 2010, p. 1646. https://cabinetbassamat.com/ codes-et-lois/id/35553?pdf=35553.

33. Loi relative à la répression de la toxicomanie et la prévention des toxicomanes promulguée par le dahir n 1-73-282 du 21-05-1974 et publiée au bulletin officiel n 3214 du 05-06-1974 ; p 928. http:// adala.justice.gov.ma/production/html/Fr/liens/..\%5C71772.htm. 